\title{
Pituitary Adenomas in Adolescent Patients with Multiple Endocrine Neoplasia Type 1
}

\author{
Ako OIWA, AKIHIRo SAKURAI, Yoshihiko SATO, TaKahiro SAKUMA, KoH YAMASHITA, \\ MIYUKI KATAI, TORU AIZAWA aNd KIYoshi HASHIZUME
}

Department of Aging Medicine and Geriatrics, Shinshu University School of Medicine, Matsumoto 390-8621, Japan

\begin{abstract}
Two juvenile patients with multiple endocrine neoplasia type 1 (MEN1) who developed pituitary adenomas are reported. The first case, a 14-year-old girl, developed prolactinoma and manifested delayed puberty and growth arrest. The second case, a 16-year-old boy, was asymptomatic and a pituitary adenoma accompanied by mild elevation of PRL and GH was identified through family screening. His growth and pubertal development was not impaired. Medication with bromocriptine was started for both cases with good therapeutic responses. These cases emphasize relevance of early screening of endocrine disorders for members of families with MEN1.
\end{abstract}

Key words: Endocrine tumor, Prolactinoma, Delayed puberty, Family screening

(Endocrine Journal 49: 635-640, 2002)

MULTIPLE endocrine neoplasia type 1 (MEN1) is an autosomally transmitted hereditary tumor syndrome that comprises hyperplastic and neoplastic disorders of the parathyroids, anterior pituitary, enteropancreas and other endocrine and non-endocrine organs [1]. Mutations of the MEN1 gene, which encodes a 610 amino acid nuclear protein referred to as menin, have been identified in most families investigated [2]. Isolation of the $M E N I$ gene enabled early diagnosis of asymptomatic gene carriers in affected families. Pituitary tumors develop in $30-70 \%$ of patients with MEN1. Mean age at onset of MEN1associated pituitary tumors is the 4th decade and its occurrence before and during puberty is very rare [3-7]. Recently, guidelines for management of MEN have been released [8]. In Japan, age to begin periodic screening and to perform genetic test for children of affected parents largely depends on

Received: July 3, 2002

Accepted: October 16, 2002

Correspondence to: Akihiro SAKURAI, M.D., Ph.D., Department of Aging Medicine and Geriatrics, Shinshu University School of Medicine, 3-1-1 Asahi, Matsumoto 390-8621, Japan personal decision of attending physicians, and there is no unified view on this issue. This is in part due to the lack of a reliable database on clinical features of Japanese patients. Furthermore, assessment of medical and psychological impact on genetic test has not been systematically evaluated.

We have recently experienced two juvenile patients with MEN1 who developed pituitary adenomas. Here we report these two cases and discuss on desirable management of this disease, especially asymptomatic young gene carriers.

\section{Case report}

\section{Case 1}

The patient was a 14 year-old girl who visited our department with complaints of primary amenorrhea and growth arrest. She was a MEN1 family member and 4 base deletion of the MEN1 gene (359del4) [9] had been identified in affected family members including her mother and grandfather (Fig. 1A). At the age of 11 , she was advised to take a screening test for MEN1. Biochemical screening revealed no ab- 
normal findings. Imaging of pituitary and pancreas was not attempted. Although annual screening was advised, she did not visit the hospital for three years. At the age of 13, she noticed her growth rate was retarded, thus she visited the hospital at the age of 14. She was $146 \mathrm{~cm}$ tall and weighed $38 \mathrm{~kg}$. Her growth chart shown in Fig. 1B revealed retardation of growth after the age of 12 . Bone age estimated by $\mathrm{X}$-rays of wrist and knee joint was appropriate for chronological age (14 y $6 \mathrm{~m}$ ) and epiphyses were about to close. Development of breast was not seen (Tanner stage 1) but that of pubic hair was normal (Tanner stage 3). Facial angiofibromas and other skin lesions were not seen [10]. Laboratory examination revealed elevation of serum PRL concentration and MRI revealed a pituitary mass (Fig. 1C). Pituitary function tests revealed normal responses to GRH, TRH and CRH. The level of PRL decreased from $861 \mathrm{ng} / \mathrm{ml}$ to $477 \mathrm{ng} / \mathrm{ml}$ by administration of TRH. Responses of LH and FSH to LHRH were

A
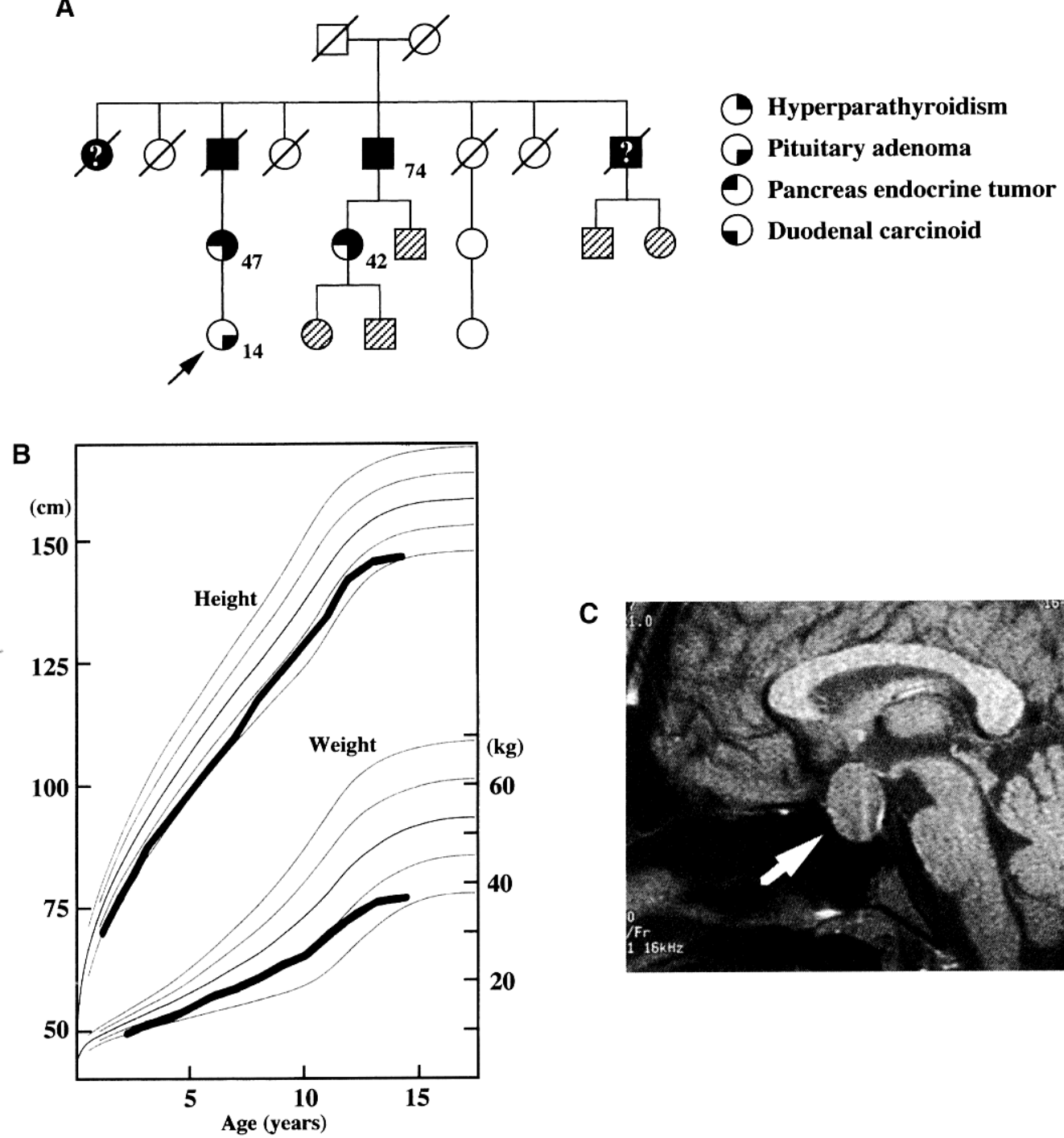

C

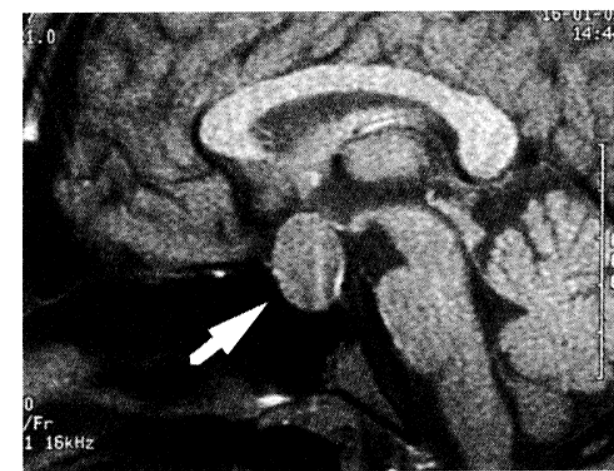

Fig. 1. A. Pedigree of case 1 (indicated by arrow). All pituitary tumors found in this family were prolactinomas. Subjects indicated with hatched symbols are possible gene carriers. Insufficient clinical information was available for subjects marked “?"”.

B. Growth chart of the patient showing early growth retardation in recent two years.

C. Sagittal T1-weighted MRI of the pituitary gland demonstrating a tumor $(20 \times 18 \times 17 \mathrm{~mm})$ extending to outside of the sella and compressing an optic chiasm. 
low normal, probably reflecting the suppressive effect of PRL (Table 1). Slight elevation of serum calcium concentration without suppression of PTH was also observed. Imaging studies of parathyroids by ultrasonography and ${ }^{99 \mathrm{~m}}$ technetium-sestamibi scintiscan were negative. CT scan of the abdomen revealed no abnormal findings in pancreas and adrenal glands. With the evidence of prolactinoma and family history, diagnosis of MEN1 was made and that was confirmed by genetic analysis, which revealed heterozygous MENI gene mutation. Medication with $5 \mathrm{mg}$ /day of bromocriptine was instituted as effectiveness of bromocriptine on prolactinomas in adolescent patients has been documented [11, 12]. After 1 month of medication, serum PRL level decreased to 27 $\mathrm{ng} / \mathrm{ml}$ and the volume of pituitary mass decreased from $3,200 \mathrm{~mm}^{3}$ to $1,980 \mathrm{~mm}^{3}$. Level of PRL and size of pituitary tumor have remained unchanged thereafter for 8 months. She had the menarche 6 months after the start of medication.

\section{Case 2}

The patient was a 15 year-old boy who visited our department for screening of MEN1. His mother was affected with MEN1 (Fig. 2A) and 1 base insertion of the MEN1 gene (1657insC) [9] had been identified. His elder sister had been diagnosed as having primary hyperparathyroidism at the age of 21 by family screening. The patient had no complaints and no abnormality was found on physical examination. His height and weight was $174 \mathrm{~cm}$ and $66 \mathrm{~kg}$, respectively, and pubertal development was appropriate for age. No skin lesions were seen [10]. Serum PRL concentration was $11.5 \mathrm{ng} / \mathrm{ml}$ and MRI of the pituitary was not taken. He visited the hospital the next year (at age 16) for periodic screening. He had been well and physical and laboratory examinations revealed no abnormal findings except for mild elevation of PRL to $30.5 \mathrm{ng} / \mathrm{ml}$ and $\mathrm{GH}$ to $6.8 \mathrm{ng} / \mathrm{ml}$ (Table 1). Pituitary MRI revealed a mass as shown in Fig. 2B. Responses to TRH, CRH and LHRH were normal. TRH increased PRL level only marginally

Table 1. Laboratory data of cases 1 and 2

\begin{tabular}{|c|c|c|c|}
\hline & Case 1 & Case 2 & normal range \\
\hline Age (year/month) & 14 y $6 \mathrm{~m}$ & 16 y $9 \mathrm{~m}$ & \\
\hline Total protein & 7.5 & 7.0 & $6.8-8.3(\mathrm{~g} / \mathrm{dl})$ \\
\hline Albumin & 4.6 & 5.0 & $4.2-5.1(\mathrm{~g} / \mathrm{dl})$ \\
\hline Calcium & 10.3 & 9.9 & $8.6-10.1(\mathrm{mg} / \mathrm{dl})$ \\
\hline Phosphate & 3.6 & 3.9 & $2.2-4.1(\mathrm{mg} / \mathrm{dl})$ \\
\hline Intact PTH & 59 & 22 & $14-66(\mathrm{pg} / \mathrm{ml})$ \\
\hline $\mathrm{GH}$ & 1.78 & 6.8 & $<5(\mathrm{ng} / \mathrm{ml})$ \\
\hline PRL & 520 & 30.5 & $1.4-14.6(\mathrm{ng} / \mathrm{ml})$ \\
\hline $\mathrm{LH}$ & 3.4 & 3.5 & $\begin{array}{c}\mathrm{M}: 0.8-4.2(\mathrm{mIU} / \mathrm{ml}) \\
\mathrm{F}: 0.4-4.1(\mathrm{mIU} / \mathrm{ml})\end{array}$ \\
\hline (peak after LHRH) & 10.5 & 42.0 & $\begin{array}{r}\mathrm{M}: 18.2-38.0(\mathrm{mIU} / \mathrm{ml}) \\
\mathrm{F}: 8.5-15.5(\mathrm{mIU} / \mathrm{ml})\end{array}$ \\
\hline FSH & 6.0 & 2.5 & $\begin{array}{r}\mathrm{M}: 2.9-10.8(\mathrm{mIU} / \mathrm{ml}) \\
\mathrm{F}: 4.8-10.4(\mathrm{mIU} / \mathrm{ml})\end{array}$ \\
\hline (peak after LHRH) & 8.5 & 6.0 & $\begin{array}{r}\mathrm{M}: 5.3-22.3(\mathrm{mIU} / \mathrm{ml}) \\
\mathrm{F}: 8.3-20.0(\mathrm{mIU} / \mathrm{ml})\end{array}$ \\
\hline Glucose & 86 & 82 & $60-110(\mathrm{mg} / \mathrm{dl})$ \\
\hline Insulin & 7.8 & 9.5 & $5-25(\mu \mathrm{U} / \mathrm{ml})$ \\
\hline Glucagon & 86 & & $23-197(\mathrm{pg} / \mathrm{ml})$ \\
\hline Gastrin & 54 & 54 & $37-172(\mathrm{pg} / \mathrm{ml})$ \\
\hline Response of GH to GRH & normal & normal & \\
\hline Response of TSH to TRH & normal & normal & \\
\hline Response of ACTH to CRH & normal & normal & \\
\hline
\end{tabular}

Normal ranges of LH and FSH are those for pubertal age group. M, male; F, female. 
A

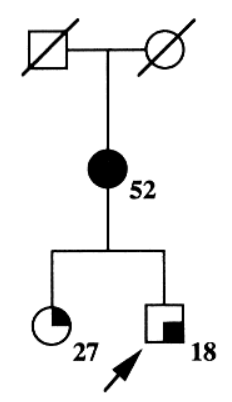

() Hyperparathyroidism

Pituitary adenoma

Pancreas endocrine tumor

Duodenal carcinoid
B

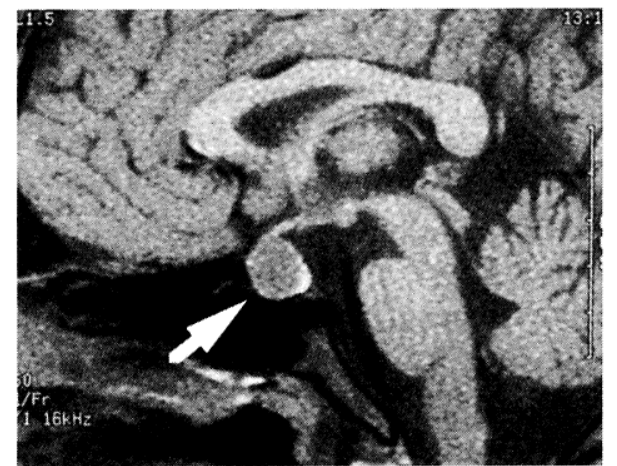

Fig. 2. A. Pedigree of case 2 .

B. Sagittal T1-weighted MRI of the pituitary gland of case 2 taken at the age of 17. A pituitary tumor with the size of $15 \times 13 \times 13 \mathrm{~mm}$ was indicated by an arrow. Normal pituitary tissue and a stalk were compressed to the right. Compression of optic nerve and involvement to cavernous sinus was not seen.

$(28.5 \mathrm{ng} / \mathrm{ml}$ to $36.7 \mathrm{ng} / \mathrm{ml})$. Abdominal CT revealed no abnormalities in pancreas and adrenal glands. Genetic analysis revealed he and his elder sister carried mutant $M E N I$ gene as does their mother. Medication with bromocriptine $(2.5 \mathrm{mg} /$ day $)$ was started and levels of PRL and GH had decreased to 3.8 $\mathrm{ng} / \mathrm{ml}$ and $0.4 \mathrm{ng} / \mathrm{ml}$, respectively, although the size of the pituitary tumor did not change 1 year after the initiation of medication.

\section{Discussion}

Case 1 in the present report manifested growth arrest as well as delayed puberty. It is established that growth of long bones requires low concentration of estrogen as well as $\mathrm{GH}$, and that both synergistically induce endochondral bone formation at cartilage growth plate $[13,14]$. Estrogen, on the other hand, induces closure of epiphysis at high concentration. Effect of PRL on bone formation is not fully understood. Although there are some experimental studies of PRL on osteoblast function [15, 16], clinical studies do not demonstrate significant influence of PRL on bone formation. Among 26 cases of prolactinoma in children reported by Colao et al., growth arrest was seen in only one case that accompanied an impaired GH secretion [17]. Mindermann and Wilson reported 72 such pediatric cases of prolactinoma and short stature was observed in $11 \%$ of patients [18]. In the latter study, however, the patient profile of GH secretion was not mentioned. It seems difficult to explain the cause of epiphyseal closure in case 1 who showed normal GH secretion, low level (prepubertal level) of estrogen and poor pubertal development. Careful observation on pituitary function and the size of prolactinoma as well as growth and pubertal development is necessary for this case.

The relevance of early genetic test for members of MEN2 family seems established considering that prophylactic thyroidectomy prevents occurrence of medullary thyroid cancer, which occurs in nearly $100 \%$ of gene carriers and is the main determinant of the mortality of patients with MEN2 [19]. On the other hand, in MEN1, malignant transformation of pancreas endocrine tumor as well as foregut carcinoids are the main causes of death [20]. The frequency of such events is not so high and the prophylactic resection of pancreas severely impairs quality of life. Therefore prophylactic surgery is not regarded as a practical choice of management of MEN1. Furthermore, hyperparathyroidism is the initial clinical manifestation for the majority of patients, which is relatively easy to identify by laboratory tests and usually not associated with morbidity, especially at young age. Therefore, it has been controversial when genetic test should be considered and when laboratory screening should be started for children of MEN1 patients. Recently published guidelines for management of MEN1 have recommended that clinical screening for parathyroid, pituitary and pancreas lesions to start at the age of 8,5 and 5 , respectively, and to continue for an entire life [8]. These recommendations are based on the age of the youngest 
patient of each lesion previously reported [5, 21-23]. For pituitary tumors in MEN1, French-Belgian study group reported the clinical features of 324 cases with MEN1 [7]. Pituitary tumors occurred in about $4 \%$ of patients before the age of 20 and the youngest onset of that was at 12 . Furthermore, pituitary tumors in MEN1 patients were clinically more aggressive than those in non-MEN1 patients as functional normalization was achieved in less than $50 \%$ of MEN1 patients but in $90 \%$ of non-MEN1 patients [7]. These reports emphasize the benefit and importance of early start of screening for asymptomatic children. However, it is to be considered that, even in single gene disorders, the clinical picture could be different among different ethnic groups. For example, the clinical course of medullary thyroid cancer in MEN2 in Japanese patients could be milder than that in Europe [24, 25].

We have treated more than 50 patients with MEN1 in our department during the last 10 years [26]. Among those, 5 patients presented non-parathyroid endocrine tumors before age of 20 . Two had pituitary tumors reported herein and three had insulinomas with clinical symptoms (ages 13, 14 and 19). No family histories were recognized for those three patients with insulinoma when their diagnosis was made. Indeed, diagnosis of MEN1 in their parents was made later through family screening. That means if diagnosis of MEN1 in their parents could have been made earlier and screening of family members had been done, insulinomas of those patients could have been diagnosed earlier and appropriately managed before their symptoms developed. These experiences made us fully aware of the importance of early screening for juvenile patients with MEN1. Based on our experience, we believe that clinical screening for children of MEN1 patients should be started before adolescence, and that such screening must include measurement of insulin, fasting glucose and PRL, because insulinoma and prolactinoma could induce serious clinical manifestations for young patients. It is to be noted that before placement of genetic test and laboratory screening for children of affected parents, physicians have to carefully consider the possible psychological impact of disclosing a previously unidentified disease trait. Differences in cultural and educational background which affect the concepts and images of hereditary diseases and genetic tests are not to be underestimated.

There is no nationwide, multicenter study on clinical features of Japanese patients with MEN1 that can be compared to those from Europe; such surveys have been carried out for MEN2 and von-Hippel Lindau disease in Japan $[24,27]$. With the aid of genetic diagnosis, it would not be difficult to collect clinical information in asymptomatic juvenile gene carriers including age-related penetrance of each phenotype of MEN1 and morbidity and mortality, if any. Establishment of a registration system for MEN1 to formulate guidelines for management of Japanese patients with MEN1 is urgently desired.

\section{References}

1. Schussheim DH, Skarulis MC, Agarwal SK, Simonds WF, Burns AL, Spiegel AM, Marx SJ (2001) Multiple endocrine neoplasia type 1: new clinical and basic findings. Trends Endocrinol Metab 12: 173-178.

2. Pannett AAJ, Thakker RV (1999) Multiple endocrine neoplasia type 1. Endocr Relat Cancer 6: 449-473.

3. Carty SE, Helm AK, Amico JA, Clarke MR, Foley TP, Watson CG, Mulvihill JJ (1998) The variable penetrance and spectrum of manifestations of multiple endocrine neoplasia type 1. Surgery 124: 11061114.

4. Scheithauer BW, Laws Jr ER, Kovacs K, Horvath E, Randall RV, Carney JA (1987) Pituitary adenomas of the multiple endocrine neoplasia type I syndrome. Semin Diagn Pathol 4: 205-211.
5. Trump D, Farren B, Wooding C, Pang JT, Besser GM, Buchanan KD, Edwards CR, Heath DA, Jackson CE, Jansen S, Lips $\mathrm{K}$, Monson JP, O'Halloran D, Sampson J, Shalet SM, Wheeler MH, Zink A, Thakker RV (1996) Clinical studies of multiple endocrine neoplasia type $1(\mathrm{MEN} 1) . Q J \operatorname{Med} 89$ : 653-669.

6. O'Brien T, O'Riordan DA, Gharib H, Scheithauer BW, Ebersold MJ, van Heerden JA (1996) Results of treatment of pituitary disease in multiple endocrine neoplasia, type I. Neurosurgery 39: 273-278.

7. Vergès $B$, Boureille $F$, Goudet $P$, Murat $A$, Beckers A, Sassolas G, Cougard P, Chambe B, Montvernay C, Calender A, The members of Groupe d'Etude des Néoplasies Endocriniennes Multiples (2002) Pituitary 
disease in MEN type 1 (MEN1): data from the FranceBelgium MEN1 multicenter study. J Clin Endocrinol Metab 87: 457-465.

8. Brandi ML, Gagel RF, Angeli A, Bilezikian JP, BeckPeccoz P, Bordi C, Conte-Devolx B, Falchetti A, Gheri RG, Lobroia A, Lips CJM, Lombardi G, Mannelli M, Pacini F, Ponder BAJ, Raue F, Skogseid B, Tamburrano G, Thakker RV, Thompson NW, Tomassetti P, Tonelli F, Wells SA Jr, Marx SJ (2001) Guidelines for diagnosis and therapy of MEN type 1 and type 2. J Clin Endocrinol Metab 86: 5658-5671.

9. Sakurai A, Shirahama S, Fujimori M, Katai M, Itakura Y, Kobayashi S, Amano J, Fukushima Y, Hashizume K (1998) Novel MEN1 gene mutations in familial multiple endocrine neoplasia type 1. J Hum Genet 43: 199-201.

10. Sakurai A, Matsumoto K, Ikeo Y, Nishio S-I, Kakizawa T, Arakura F, Ishihara Y, Saida T, Hashizume $\mathrm{K}$ (2000) Frequency of facial angiofibromas in Japanese patients with multiple endocrine neoplasia type 1. Endocr J 47: 569-573.

11. Howlett TA, Wass JAH, Grossman A, Plowman PN, Charlesworth M, Touzel R, Rees LH, Savage MO, Besser GM (1989) Prolactinomas presenting as primary amenorrhoea and delayed or arrested puberty: response to medical therapy. Clin Endocrinol 30: 131140.

12. Tyson D, Reggiardo D, Sklar C, David R (1993) Prolactin-secreting macroadenomas in adolescents. Response to bromocriptine therapy. Am J Dis Child 147: 1057-1061.

13. Nilsson LO, Boman A, Savendahl L, Grigelioniene G, Ohlsson C, Ritzen EM, Wroblewski J (1999) Demonstration of estrogen receptor-beta immunoreactivity in human growth plate cartilage. J Clin Endocrinol Metab 84: 370-373.

14. Juul A (2001) The effects of oestrogens on linear bone growth. Hum Reprod Update 7: 303-313.

15. Clément-Lacroix $P$, Ormandy $C$, Lepescheux L, Ammann P, Damotte D, Goffin V, Bouchard B, Amling M, Gaillard-Kelly M, Binart N, Baron R, Kelly PA (1999) Osteoblasts are a new target for prolactin: analysis of bone formation in prolactin receptor knockout mice. Endocrinology 140: 96-105.

16. Coss D, Yang L, Kuo CB, Xu X, Luben RA, Walker AM (2000) Effects of prolactin on osteoblast alkaline phosphatase and bone formation in the developing rat. Am J Physiol Endocrinol Metab 279: E1216E1225.

17. Colao A, Loche S, Cappa M, Di Sarno A, Landi ML, Sarnacchiaro F, Facciolli G, Lombardi G (1998) Prolactinomas in children and adolescents. Clinical presentation and long-term follow-up. J Clin Endocrinol Metab 83: 2777-2780.
18. Mindermann T, Wilson CB (1995) Pediatric pituitary adenomas. Neurosurgery 36: 259-269.

19. Sanso GE, Domene HM, Garcia R, Pusiol E, de M, Roque M, Ring A, Perinetti H, Elsner B, Iorcansky S, Barontini M (2002) Very early detection of RET proto-oncogene mutation is crucial for preventive thyroidectomy in multiple endocrine neoplasia type 2 children: presence of $\mathrm{C}$-cell malignant disease in asymptomatic carriers. Cancer $94:$ 323-330.

20. Wilkinson S, Teh BT, Davey KR, McArdle JP, Young M, Shepherd J (1993) Cause of death in multiple endocrine neoplasia type 1. Arch Surg 128: 683690.

21. Betts JB, O'Malley BP, Rosenthal FD (1980) Hyperparathyroidism: a prerequisite for Zollinger-Ellison syndrome in multiple endocrine adenomatosis Type 1report of a further family and a review of the literature. $Q J$ Med 49: 69-76.

22. Stratakis CA, Schussheim DH, Freedman SM, Keil MF, Pack SD, Agarwal SK, Skarulis MC, Weil RJ, Lubensky IA, Zhuang Z, Oldfield EH, Marx SJ (2000) Pituitary macroadenoma in a 5-year-old: an early expression of multiple endocrine neoplasia type 1. J Clin Endocrinol Metab 85: 4776-4780.

23. Giraud S, Zhang CX, Serova-Sinilnikova O, Wautot V, Salandre J, Buisson N, Waterlot C, Bauters C, Porchet N, Aubert JP, Emy P, Cadiot G, Delemer B, Chabre O, Niccoli P, Leprat F, Duron F, Emperauger B, Cougard P, Goudet P, Sarfati E, Riou JP, Guichard S, Rodier M, Calender A (1998) Germ-line mutation analysis in patients with multiple endocrine neoplasia type 1 and related disorders. Am J Hum Genet 63: 455-467.

24. Iihara $M$, Yamashita $T$, Okamoto $T$, Kanbe $M$, Yamazaki K, Egawa S, Yamaguchi K, Obara T (1997) A nationwide clinical survey of patients with multiple endocrine neoplasia type 2 and familial medullary thyroid carcinoma in Japan. Jpn J Clin Oncol 27: 128-134.

25. Raue F, German MTC/MEN Study Group (1998) German medullary thyroid carcinoma/multiple endocrine neoplasia registry. Langenbecks Arch Surg 383: 334-336.

26. Katai M, Sakurai A, Itakura Y, Ikeo Y, Nakajima K, Hara M, Iijima S, Kaneko T, Kobayashi M, Ichikawa $\mathrm{K}$, Aizawa T, Hashizume K (1997) Multiple endocrine neoplasia type 1 is not rare in Japan. Endocr $J 44$ : 841-845.

27. Yoshida M, Ashida S, Kondo K, Kobayashi K, Kanno H, Shinohara N, Shitara N, Kishida T, Kawakami S, Baba M, Yamamoto I, Hosaka M, Shuin T, Yao M (2000) Germ-line mutation analysis in patients with von Hippel-Lindau disease in Japan: an extended study of 77 families. Jpn J Cancer Res 91: 204-212. 